AJIE - Asian Journal of Innovation and Entrepreneurship

(e-ISSN: 2477- 0574; p-ISSN: 2477-3824)

Vol. 02, No. 01, January 2017

\title{
PENENTUAN STRATEGI PEMASARAN PRODUK 'DARMA KARYA' DENGAN MENGGUNAKAN ANALISIS GRAND MATRIX SWOT
}

\author{
Nur Feriyanto ${ }^{1}$ \\ ${ }^{1}$ Program Studi Ekonomi Pembangunan, Universitas Islam Indonesia \\ e-mail: nur.feriyanto@uii.ac.id
}

\begin{abstract}
Small Medium Entreprises (SMEs) have contributed significantly in regional and national economics. Stakeholders in the region have much expected that SMEs should play more important role as solution in decreasing unemployment and developing small scale business. Kelompok Makanan Olahan Darma Karya (Darma Karya Processing Food Business Group) in Harjobinangun Village, Pakem, Sleman, DIY is one of small medium enterprises that has been continuously received supervision from the Directorate of Research and Community Service, Universitas Islam Indonesia (DPPM UII). Over the time, the development of this business group have been much progressive. However, this group still need assistance in developing their business, viewing the fact that the business rivalry has been more competitive. In such, it is expected that the business group can further develop and contribute to the economic development in the region of Sleman. The decision to have a proper marketing strategy is one of the efforts offered by the management and economic experts from DPPM UII in supervising Darma Karya Business Group. This marketing strategy utilizes Grand Matrix SWOT.
\end{abstract}

Keywords: Small Medium Enterprises (SME), Darma Karya, Marketing Strategy, SWOT

\begin{abstract}
ABSTRAK
Bisnis yang dilakukan oleh Usaha Mikro, Kecil dan Menengah (UMKM) sudah banyak mengisi kegiatan ekonomi baik di daerah maupun nasional. Stakeholder perekonomian di daerah sangat berharap bahwa UMKM tersebut dapat terus berkembang sehingga menjadi salah satu solusi bagi persoalan pengurangan pengangguran dan pengembangan usaha rakyat di daerah. Kelompok Makanan Olahan Darma Karya di desa Harjobinangun, Pakem, Sleman, DIY adalah salah satu kelompok usaha yang berada di bawah pembinaan Direktorat Penelitian dan Pengabdian Masyarakat Universitas Islam Indonesia (DPPM UII). Perkembangan kelompok usaha ini cukup maju tetapi masih harus dibina mengingat persaingan bisnis sangat ketat, sehingga bisnis ini dapat terus mengembangkan usahanya dan dapat lebih berperan dalam perekonomian khususnya di Kabupaten Sleman. Penentuan strategi pemasaran yang tepat menjadi salah satu upaya yang dilakukan ahli ekonomi dan manajemen di DPPM UII dalam membina kelompok usaha Darma Karya ini. Penentuan strategi pemasaran menggunakan Grand Matrix SWOT.
\end{abstract}

Kata kunci: UMKM, Darma Karya, strategi pemasaran, SWOT 


\section{LATAR BELAKANG}

UMKM telah terbukti menjadi salah satu jenis usaha yang mampu bertahan dan terus berkembang dalam kondisi ekonomi yang sulit. Hal ini didasari oleh kemampuan usaha tersebut bersikap dalam kondisi ekonomi yang berubah karena dimilikinya sifat yang fleksibel. Di samping itu usaha khususnya mikro dan kecil telah mampu menjadi salah satu solusi yang efektif bagi daerah dalam menanggulangi persoalan pengangguran karena usaha ini terbukti mampu menyerap tenaga kerja yang banyak tanpa mensyaratkan tingkat pendidikan yang tinggi. Usaha ini dikenal mampu menyerap tenaga kerja yang berpendidikan rendah tetapi memilik keterampilan yang cukup baik. Keterampilan dari sumberdaya manusia yang bekerja di usaha mikro dan kecil dapat dikembangkan melalui berbagai kegiatan pelatihan atau on the job training.

Makanan olahan menjadi suatu produk yang sangat tinggi peminatnya karena produk ini dapat mengisi kebutuhan konsumen yang beragam. Di sampin itu bahan baku makanan olahan sangat banyak baik dari hasil pertanian, perikanan, ataupun peternakan. Masyakarat desa pada umumnya sangat antusias masuk dalam UMKM yang menjual produk olahan, karena di samping memiliki waktu luang untuk bekerja, usaha ini juga sangat potensial untuk berkembang mengingat pasar (konsumen) yang terus berkembang. Lembaga-lembaga pemerintah serta Perguruan Tinggi saling bekerjasama di dalam melakukan pembinaan bagi usaha ini melalui kelompok usaha, agar kelompok usaha dapat mengisi dan berperan aktif dalam perekonomian daerah.

DPPM UII merupakan salah satu lembaga di Universitas Islam Indonesia yang antusias dan memiliki kemampuan dalam melakukan pembinaan terhadap UMKM, baik di DIY ataupun di Indonesia. Salah satu kelompok usaha makanan olahan di Desa Harjobinangun, Sleman, DIY yang telah cukup lama menjadi binaan DPPM UII adalah Kelompok Usaha Makanan Olahan Darma Karya. Kelompok usaha ini memiliki sekitar 12 jenis usaha, di antarananya keripik jamur, keripik tempe, jamur krispi, telur asin, keripik bayam, JCO, olahan salak, olahan singkong, abon ikan, abon ayam, ceriping ketela, dan minuman jahe merah. Perkembangan usaha ini sangat pesat karena ada pembinaan manajemen, bantuan alat serta arahan inovasi produk dan strategi pemasaran produk.

\section{KAJIAN LITERATUR}

Kajian tentang pengembangan dan permasalahan UMKM (Small Medium Enterprise/SME) dilakukan di beberapa negara. Sebagaimana yang dilakukan oleh Aldaba (2012) yang menemukan bahwa hampir semua UMKM di Asia Tenggara mengalami hambatan yang sama besar untuk mengakses fasilitas keuangan, mengembangkan dukungan teknologi, dan meningkatkan kualitas sumber daya manusia. Hal ini membutuhkan dukungan dari pemerintah masing-masing negara baik dari segi kebijakan, landasan hukum, maupun keuangan.

Perhatian penuh pemerintah bagi UMKM sudah dilakukan oleh pemerintah Afrika Selatan. Dalam penelitian Cant (2012) yang dilakukan di negara tersebut, menyebutkan bahwa sektor UMKM di Afrika Selatan telah menjadi perhatian pemerintah dalam rangka asistensi ekonomi dan penciptaan lapangan kerja baru. Pemerintah berharap sektor UMKM dapat menyediakan 500 ribu lapangan kerja baru setiap tahun untuk 10 tahun kedepan. 
Penelitian itu juga mengungkapkan bahwa terdapat hubungan yang positif antara kesuksesan bisnis usaha kecil dan menengah dengan strategi pemasaran yang digunakan. Untuk itu tantangan yang dihadapi pemerintah saat ini adalah menyediakan pelatihan-pelatihan bagi usaha kecil untuk meningkatkan kemampuan strategi marketing yang handal.

Temuan itu dikuatkan oleh Suryaningrum (2012) yang melakukan penelitian di Indonesia. Peneliti menemukan bahwa sektor UMKM di Indonesia sebagian besar dimiliki oleh penduduk pribumi, bersifat labor intensif, memiliki tenaga kerja yang kurang terdidik, dan memiliki sumber pendanaan dari tabungan pribadi. Permasalahan yang biasa didapati di sektor UMKM adalah kendala perkembangan usaha dikarenakan arah kebijakan yang cenderung sesuai dengan kemauan keluarga pemilik menyebabkan perkembangan usaha menjadi tidak meningkat secara signfikan. Artinya sektor UMKM yang semakin tidak berorientasi pada keluarga akan menyebabkan usaha tersebut semakin dapat meningkatkan performanya. Kemudian terkait dengan itu, Haryani (2012) menambahkan bahwa sistem akuntansi bagi UMKM juga dapat mendukung upaya peningkatan efektifitas dan efisiensi perusahaan. Penggunaaan sistem akuntansi yang baik dalam operasional perusahaan akan dapat meningkatkan proses manajemen dan mencapai keunggulan kompetifif.

Permasalahan lain yang juga dihadapi oleh perusahaan bersakala kecil di Indonesia adalah terkait dengan Hak Kekayaan Intelektual (HKI). Sinaga (2013) menyebutkan bahwa meskipun HKI diketahui memiliki manfaat bagi perkembangan UMKM, namun masih sangat sedikit yang menggunakannya. Hal ini disebabkan oleh kurangnya kapasitas pengetahuan UMKM mengenai HKI sebagai sebuah strategi bisnis yang menjanjikan. Perusahaan kecil dan menengah di Indonesia masih meyakini bahwa pemasaran adalah strategi yang paling utama dalam rangka meningkatkan penjualan mereka.

Strategi pemasaran, menurut Suryana, Bayu \& Jatnika (2013), memegang peran yang sangat penting bagi perkembangan perusahaan. Penelitian yang mereka dilakukan di Cimahi, Jawa Barat, Indonesia membuktikan hal tersebut. Sebagain besar pemilik UMKM di Cimahi mengetahui bahwa pemasaran, terutama melalui e-commerce dapat meningkatkan penjualan produk yang sangat signifikan. Namun hal ini belum dilakukan oleh semua pemilik usaha, sebabnya adalah kurangnya fasilitas pendukung dan sumberdaya manusia yang dapat memanfaatkan internet sebagai metode promosi yang handal. Inovasi-inovasi demikian yang dibutuhkan oleh usaha mikro, kecil dan menengah agar tetap bisa bertahan di tengah persaingan bisnis yang ketat. Kusumastuti, Safitri, \& Khaifan (2015) menemukan bahwa kapabilitas perusahaan dalam menghasilkan inovasi dipengaruhi oleh manajemen kinerja dan dukungan sosial. Penelitian ini mereka lakukan di Cirebon, Jawa Barat, di mana ditemukan bahwa usaha kecil dan menengah yang memiliki kinerja manajemen dan memiliki dukungan sosial yang baik dari masyarakat di lingkungannya maka akan dapat menciptakan karyawan yang inovatif baik secara eksploitatif maupun eksploratif.

Sebagaimana dikemukanan oleh Lamprinopoulou \& Tregear (2011), serta Franco, Santos, Ramalho \& Nunes (2014) bahwa strategi pemasaran sangat 
dibutuhkan oleh perusahaan, akan tetapi strategi pemasaran bagaimana yang perlu digunakan adalah tergantung pada ukuran dan tujuan perusahaan tersebut. Penelitian mereka di Portugal mendapati bahwa untuk ukuran perusahaan seperti UMKM strategi pemasaran yang digunakan adalah pemasaran informal dan atraktif terhadap pasar, artinya UMKM membutuhkan pemasaran yang kreatif dan mudah diterima pasar. Hasil penelitian dari Resnick, Cheng, Brindley \& Foster (2011) menghasilkan temuan bahwa strategi pemasaran yang bisa dilakukan oleh sektor UMKM adalah pemasaran yang memiliki sifat customer engangement, networking, dan getok tular antar sesama konsumen.

Analisis penentuan strategi pemasaran menggunakan Grand Matrix SWOT pada penelitian ini bertujuan untuk memilih bagaimana pemasaran yang tepat yang perlu digunakan oleh obyek penelitian. Analisis SWOT sudah banyak digunakan oleh beberapa ahli ekonomi di dunia. Helms \& Nixon (2010) pernah melakukan penelitian mengenai penggunaan Analisis SWOT, menurutnya, analisis SWOT akhir-akhir ini banyak digunakan oleh organisisai untuk menentukan langkah dan keputusan apa yang perlu diambil. Lebih jauh lagi, analisis SWOT juga banyak digunakan oleh perusahaan berskala kecil, menengah, dan besar. Menambahkan hal tersebut, Subramoniam, El-Essai, Al-Marashadi \& Al-Kindi (2010) juga menggunakan Analisis SWOT untuk mengetahui strategi apa yang perlu diambil oleh pemerintah Oman dalam rangka meningkatkan kunjungan wisatawan mancanegara. Ia kemudian mendapati bahwa pemerintah Oman perlu melakukan strategi peningkatan jangka panjang dengan prioritas yang tinggi pada sektor Pariwisata
Pendidikan dan Pelatihan. Selain itu jaminan keamanan wisatawan juga perlu ditingkatkan, serta perlunya melakukan restorasi bangunan kuno agar menjadi lebih menarik bagi wisatawan.

Analisis SWOT juga pernah dilakukan oleh Ke, Zhao, Wang \& Wang (2009) untuk menganalisa perusahaanperusahaan domestik dalam mengembangkan proyek infrastruktur di China. Mereka menemukan bahwa kekuatan perusahaan-perusahaan domestik di China berada pada beberapa program seperti kemampuan mengeksplorasi pasar baru, operasi bisnis yang independen, manajemen dan struktur organisasi yang baik, serta kompetensi pasar yang memadai. Sementara untuk kelemahannya berada pada kemampuan negosiasi, permasalahan pendanaan dan investasi, serta pembangunan yang tidak berkelanjutan. Sedangkan Alshomroni \& Qamar (2012) melakukan kajian untuk menganalisis pengimplementasian EGovernment di Arab Saudi. Menurut mereka penggunaan analisis SWOT dengan metode TOWS Matrix menyimpulkan bahwa pemerintah Arab Saudi perlu melakukan beberapa strategi penerapan egovernment di antaranya; user centric, bridging digital, good communication, dan citizen awareness.

Strategi formulasi Matrix SWOT juga digunakan oleh Mirzakhani, Parsaamal \& Golzar (2014) untuk menganalisis strategi pemasaran beberapa perusahaan di Iran. Metodologi penelitian yang digunakan pada penelitian tersebut adalah analisis SWOT baik secara internal maupun eksternal, dengan penentuan prioritas utamanya menggunakan Quantitative Strategic Planning Matrix (QSPM). Hasil penelitian mereka membuktikan bahwa perusahaan yang 
diteliti dalam kondisi baik, dilihat dari faktor internal maupun eksternal. Selain itu hasil penelitian juga menyarankan perusahaan untuk menggunakan strategi agresif (strategi pertumbuhan) dalam rangka mempengaruhi pasar. Hal ini dilakukan karena beberapa perusahaan di Iran sudah tergolong industri yang besar sehingga penguasaan pasar menggunakan strategi agresif sangat tepat diimplementasikan.

\section{PERMASALAHAN}

Perkembangan penjualan produk dari kelompok usaha makanan olahan meskipun cukup baik tetapi juga menghadapi persaingan yang tidak kecil. Usaha sejenis yang terus tumbuh dan menjadi kompetitor menharuskan kelompok usaha Darma Karya harus terus melakukan inovasi produk, mengembangkan strategi pemasaran yang tepat serta memanfatkan perkembangan teknologi yang begitu pesat berkembang. Oleh karena ketatnya persaingan yang ada maka para pelaku usaha ini harus disadarkan bahwa usahanya bukan lagi usaha sampingan sebagai pengisi waktu luang tetapi sudah harus lebih diseriusi untuk dikelola dan dikembangkan secara baik.

DPPM UII tidak lelah-lelahnya terus berusaha mendampingi usaha ini di antaranya memberikan motivasi, memberikan perbaikan manajemen usaha, menambah fasiltas usaha agar para pelaku usaha yang mayoritas ibu-ibu rumah tangga di desa Harjobinagun, Sleman, DIY ini terus memiliki bekal manajemen dan keterampilan yang terus berkembang sesuai perkembangan ilmu dan teknologi. DPPM UII bekerjasama dengan Pemda Sleman dan Dinas terkait bersinergi untuk secara serius membina kelompok ini agar maju dan bertambah perannya dalam ikut mengembangkan ekonomi daerah. Wujud nyata mulai terlihat dengan semakin besarnya volume dan pendapatan dari penjualan kelompok usaha ini. Wilayah pemasarannya mulai berkembang tidak hanya di Kabupaten Sleman, tetapi sudah mulai masuk ke kabupaten/kota lainnya di DIY. Tentunya ini hal yang menggembirakan tetapi sekaligus tantangan bagi manajemen usaha Darma Karya. Semakin luas wilayah pemasaran suatu produk maka tingkat persaingan akan semakin ketat karena semakin banyak kompetitor yang harus dihadapi serta akan banyak ancaman tetapi sekaligus peluang yang terbuka bagi usaha yang serius mau maju. Diperlukan starategi pemasaran yang tepat bagi produk yang dijual oleh kelompok usaha makanan olahan Darma Karya. 

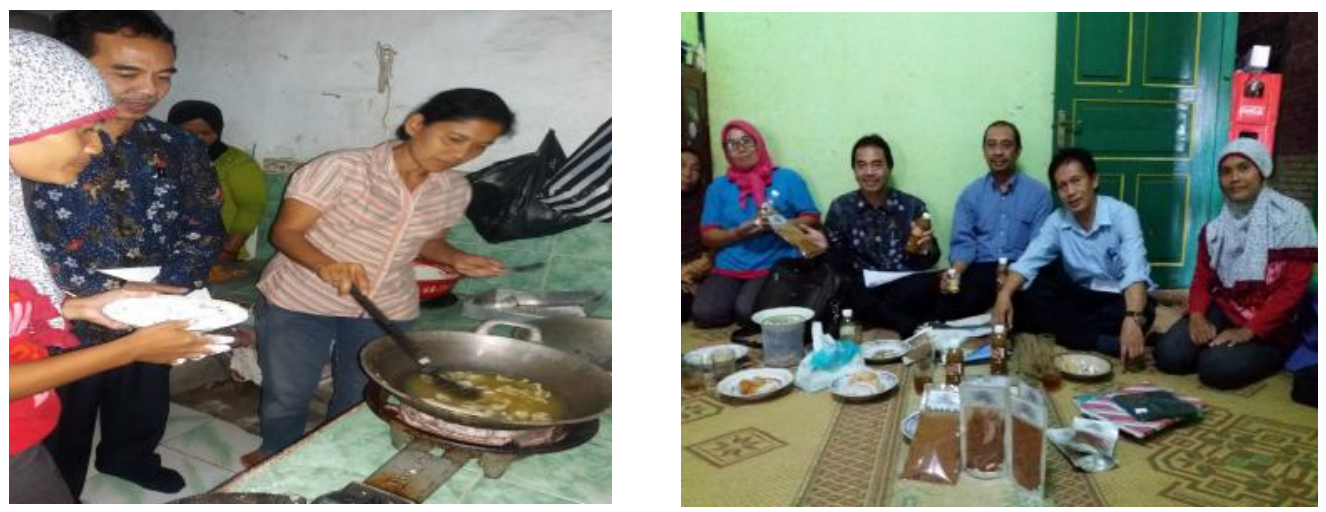

Gambar 1. Pendampingan Pengembangan Usaha di UMKM Darma Karya
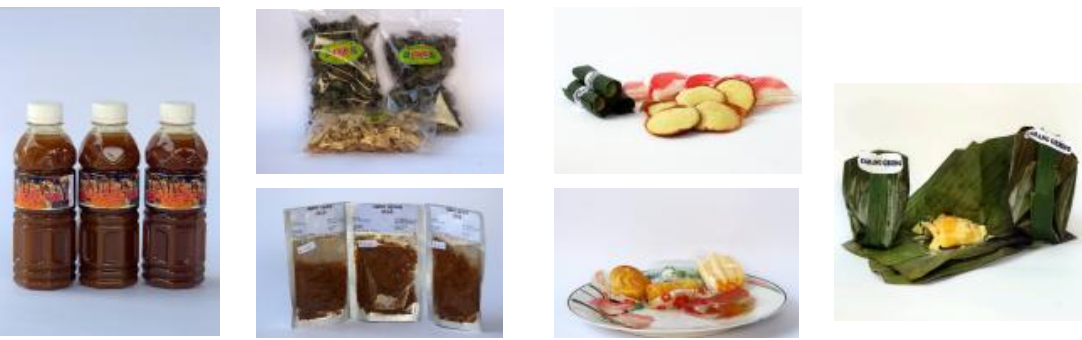

Gambar 2. Contoh Produk yang dihasilkan UMKM Darma Karya

\section{METODE PENELITIAN}

\section{1) Sumber Data}

Data penelitian ini bersumber dari jawaban kuesioner yang diberikan konsumen produk makanan olahan Darma Karya dengan jumlah 30 orang. Konsumen adalah konsumen yang sudah mengenal baik produk Darma Karya dengan minimal pembelian 3 (tiga) kali. Konsumen tersebar di Kabupaten Sleman, baik yang mengkonsumsi produk karena memesan dari produsen/pelaku usaha ataupun membeli produk langsung dari penjual.

\section{2) Pengumpulan Data}

\subsection{Skala Linkert}

Data dari jawaban kuesioner menggunakan skala Linkert 1-4 dari daftar pertanyaan ada 4 (empat) penilaian yaitu: $1=$ sangat tidak bagus; $2=$ tidak bagus; $3=$ bagus; $4=$ sangat bagus. Sedangkan untuk pembobotan digunakan 4 (empat) penilaian juga yaitu: $1=$ sangat tidak penting; $2=$ tidak penting; $3=$ penting; $4=$ sangat penting.

\subsection{Uji Validitas dan Reliabilitas}

Sebelum kuesioner diberikan ke konsumen untuk diijawab, kuesioener terlebih dahulu harus lolos uji Validitas dan Reliablitas. Uji Validitas adalah uji untuk melihat apakah alat ukur yang berupa pertanyaan-pertanyaan dapat mengukur dengan baik datau tidak. Uji Validitas menggunakan teknik koreksi product moment angka besar (Karl Pearson). Sedangkan uji Reliabilitas adalah uji yang menunjukkan sejauh mana alat ukur dapat dipercaya untuk tujuan prediksi dan diagnosis. Teknik yang digunakan dengan menggunakan korelasi product moment dan rumus Spearman Brow.

\section{3) Variabel Penelitian}

\section{a) Variabel Internal}

adalah variabel yang berada dalam usaha tersebut dan dapat dikendalikan oleh internal usaha, yang meliputi: 
a.1. Merek produk yaitu merek yang tercantum pada produk yang dijual yaitu tulisan dan simbol Darma Karya.

a.2. Kualitas produk yaitu standar mutu dari produk yang dijual dan dapat dinilai oleh konsumen.

a.3. Penampilan produk yaitu wujud produk yang dapat dilihat oleh konsumen.

a.4. Ketersediaan produk di pasar yaitu kemudahan yang dirasakan konsumen untuk memperoleh produk di pasar.

a.5. Pelayanan pemesanan produk yaitu layanan oleh produsen kepada konsumen dalam memenuhi kebutuhan produk.

a.6. Promosi pemasaran yaitu arus informasi dari produsen ke konsumen untuk mengedukasi, memberi informasi produk, mengarahkan dan mendorong konsumen agar membeli produk.

a.7. Harga sesuai kualitas yaitu kesepadanan antara harga jual produk dengan kualitas produknya.

a.8. Citra produk yaitu image yang melekat pada produk terkait dengan kualitas, reputasi, dan manfaat produk.

\section{b) Variabel Eksternal}

adalah variabel yang berada di luas usaha tersebut dan tidak dapat dikendalikan oleh internal usaha, yang meliputi: b.1. Daya beli konsumen yaitu kemampuan konsumen dalam membelanjakan uangnya.

b.2. Perubahan pemasaran karena teknologi yaitu penerapan pengetahuan ilmiah dan teknik untuk pengembangkan cara pemasaran melalui berbagai media.

b.3. Inovasi produk yaitu pengembangan produk yang bersifat memberi nilai tambah kepada konsumen.

b.4. Pertumbuhan pasar yaitu penambahan konsumen dalam pemasaran produk.

b.5. Kondisi persaingan yaitu keadaan persaingan dari produk sejenis di pasar.

\section{4) Alat Analisis}

Penentuan starategi pemasaran produk makanan olahan Darma Karya dilakukan dengan menggunakan analisis Grand Matrix SWOT (Srengths, Weaknesses, Opportunities, Threaths). Alat analisis ini membagi matrix ke dalam 4 (empat) kuadran yaitu Kuadran I, II, III, dan IV. Makna tiap kuadran dalam Grand Matrix SWOT adalah sebagai berikut:

Kuadran I: Kuadran ini menemptakan posisi usaha sangat menguntungkan, karena usaha memiliki kekuatan dan peluang untuk mengembangkan usahanya secara optimal. Strategi yang dapat dilakukan adalah stategi agresif atau strategi pertumbuhan (Growth Strategy). 


\section{Opportunities}

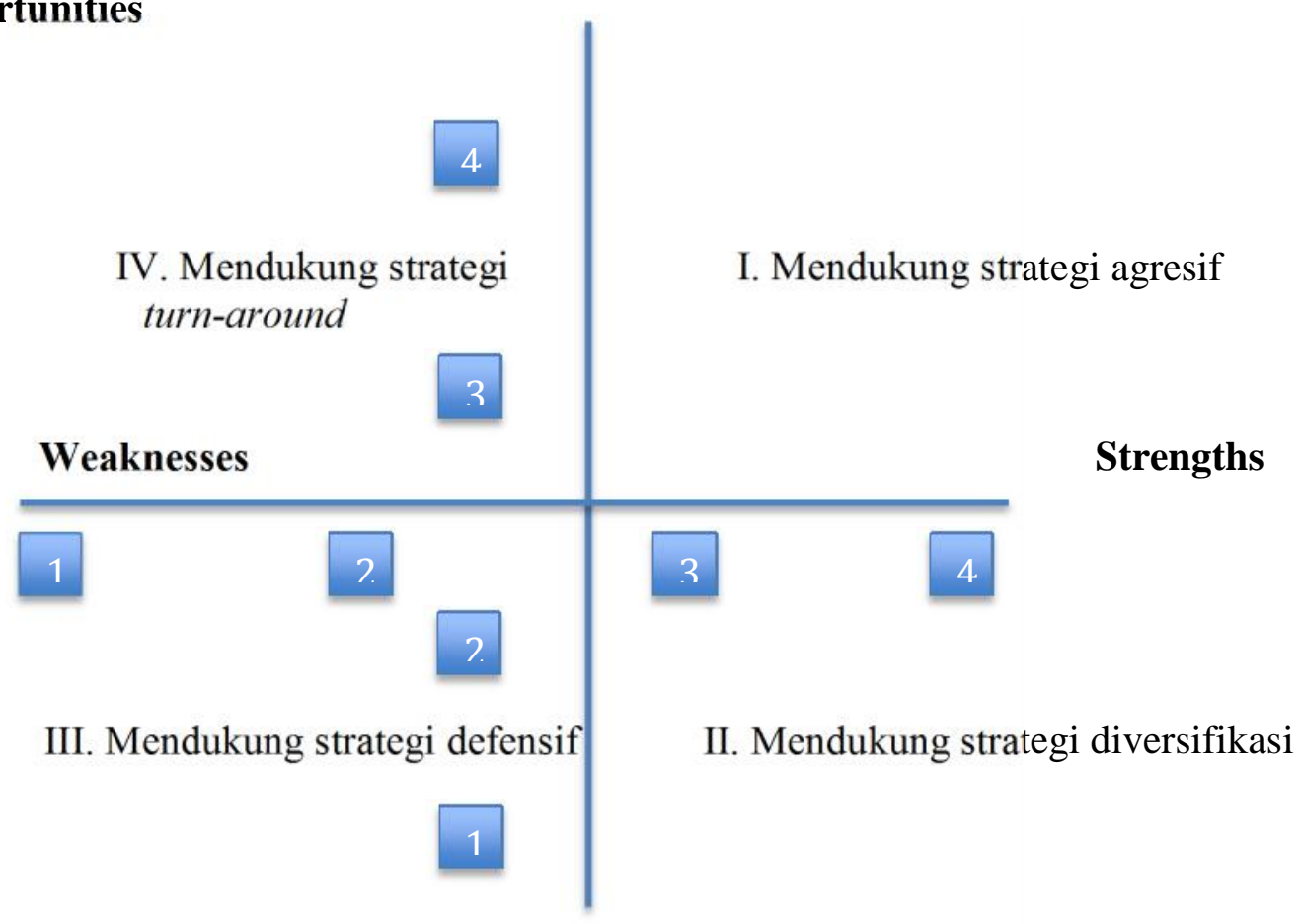

\section{Threaths}

Kuadran II: Kuadran ini memposisikan usaha memiliki kekuatan sebagai variabel internal tetapi juga menghadapi ancaman dari sisi eksternal. Strategi yang dapat dilakukan adalah strategi diversifikasi (produk/pasar).

Kuadran III: Kuadran ini menempatkan usaha pada posisi yang sangat lemah (tidak menguntungkan) karena usaha hanya dapat bertahan agar tidak gulung tikar dalam menghadapi ancaman, dalam kondisi memiliki kelemahan internal. Strategi yang dapat dilakukan adalah strategi defensif.

Kuadran IV: Kuadran ini mendudukkan posisi usaha dalam peluang yang besar untuk bisa berkembang tetapi juga memiliki beberapa kendala yang merupakan kelemahan dari internal usaha.
Strategi yang dapat dilakukan adalah strategi turn-around.

\section{HASIL DAN PEMBAHASAN}

Data yang dihimpun dari jawaban kuesioner yang diisi konsumen produk makanan olahan Darma Karya, kemudian dilakukan verifikasi untuk mengetahui bobot dan nilai dari masing-masing variabel, baik variabel internal ataupun variabel eksternal. Data tersebut setelah lolos verifikasi kemudian diolah dengan langkah-langkah sebagai berikut:

1) Memberikan bobot (weight) pada masing-masing variabel.

Nilai bobot dari masig-masing variabel akan memberikan informasi besar kecilnya pengaruh atau seberapa besar arti penting variabel tersebut dilihat dari keseluruhan variabel yang ada. Total bobot dari seluruh variabel adalah 1 . 
Tabel 1

Bobot Variabel Internal

\begin{tabular}{|c|l|c|}
\hline No & \multicolumn{1}{|c|}{ Faktor-faktor } & Bobot \\
\hline 1 & Merek produk & 0,1232 \\
\hline 2 & Kualitas produk & 0,1244 \\
\hline 3 & Penampilan produk & 0,1280 \\
\hline 4 & Ketersediaan produk di pasar & 0,1268 \\
\hline 5 & Pelayanan pemesanan produk & 0,1209 \\
\hline 6 & Promosi pemasaran & 0,1280 \\
\hline 7 & Harga sesuai kualitas & 0,1268 \\
\hline 8 & Citra produk & 0,1220 \\
\hline Total & & 1,0000 \\
\hline
\end{tabular}

sumber: data primer

Tabel 2.

Bobot Variabel Eksternal

\begin{tabular}{|c|l|c|}
\hline No & \multicolumn{1}{|c|}{ Faktor-faktor } & Bobot \\
\hline 1 & Daya beli konsumen & 0,1841 \\
\hline 2 & Perubahan pemasaran karena teknologi & 0,2690 \\
\hline 3 & Inovasi produk & 0,1912 \\
\hline 4 & Pertumbuhan pasar & 0,1752 \\
\hline 5 & Kondisi persaingan & 0,1805 \\
\hline Total & & 1,0000 \\
\hline
\end{tabular}

sumber: data primer

2) Menghitung nilai tertimbang (skor) sebagai hasil kali bobot dengan ranking (nilai mean)
Setelah menghitung nilai rata-rata (mean) dari setiap variabel, baik variabel internal maupun eksternal maka dihitung nlai tertimbang (skor)-nya.

Tabel 3

Skor Variabel Internal

\begin{tabular}{|c|l|c|c|c|}
\hline No & \multicolumn{1}{|c|}{ Faktor-faktor } & Bobot & Ranking & Skor \\
\hline 1 & Merek produk & 0,1232 & 2,4670 & 0,3039 \\
\hline 2 & Kualitas produk & 0,1244 & 3,2670 & 0,4064 \\
\hline 3 & Penampilan produk & 0,1280 & 2,4330 & 0,3114 \\
\hline 4 & Ketersediaan produk di pasar & 0,1268 & 3,2670 & 0,1443 \\
\hline 5 & Pelayanan pemesana produk & 0,1209 & 3,3000 & 0,3990 \\
\hline 6 & Promosi pemasaran & 0,1280 & 3,2330 & 0,4138 \\
\hline 7 & Harga sesuai kualitas & 0,1268 & 3,3000 & 0,4184 \\
\hline 8 & Citra produk & 0,1220 & 2,8670 & 0,3498 \\
\hline Total & & 1,0000 & 24,1340 & 3,0170 \\
\hline
\end{tabular}

sumber: data primer 
Tabel 4.

Skor Variabel Eksternal

\begin{tabular}{|c|l|c|l|c|}
\hline No & \multicolumn{1}{|c|}{ Faktor-faktor } & Bobot & Ranking & Skor \\
\hline 1 & Daya beli konsumen & 0,1841 & 2,9667 & 0,5462 \\
\hline 2 & Perubahan pemasaran karena teknologi & 0,2690 & 2,4670 & 0,6636 \\
\hline 3 & Inovasi produk & 0,1912 & 3,3670 & 0,6438 \\
\hline 4 & Pertumbuhan pasar & 0,1752 & 2,7670 & 0,4848 \\
\hline 5 & Kondisi persaingan & 0,1805 & 3,1000 & 0,5596 \\
\hline Total & & 1,0000 & 14,6677 & 2,8979 \\
\hline
\end{tabular}

sumber: data primer

\section{Perumusan Strategi Pemasaran}

Dilihat dari nilai skor analisis data dihasilkan koordinasi produk Darma Karya terletak dari variabel internal di titik 3,0170 dan variabel eksternal di titik 2,8979. Dilihat dari gambar Grand Matrix SWOT, posisi produk Darma Karya berada di kuadran I, yaitu suatu posisi di mana produk Darma Karya memiliki kekuatan dan peluang dalam bisnisnya. Artinya kelompok usaha Darma Karya dapat secara maksimal menggunakan kekuatan yang dimilikinya untuk meraih peluang bisnis yang masih terbuka lebar, agar bisnisnya dapat dikembangkan lebih baik lagi.

Menggunakan Grand matrix SWOT maka posisi bisnis Darma Karya terletak pada:

\section{Opportunities}

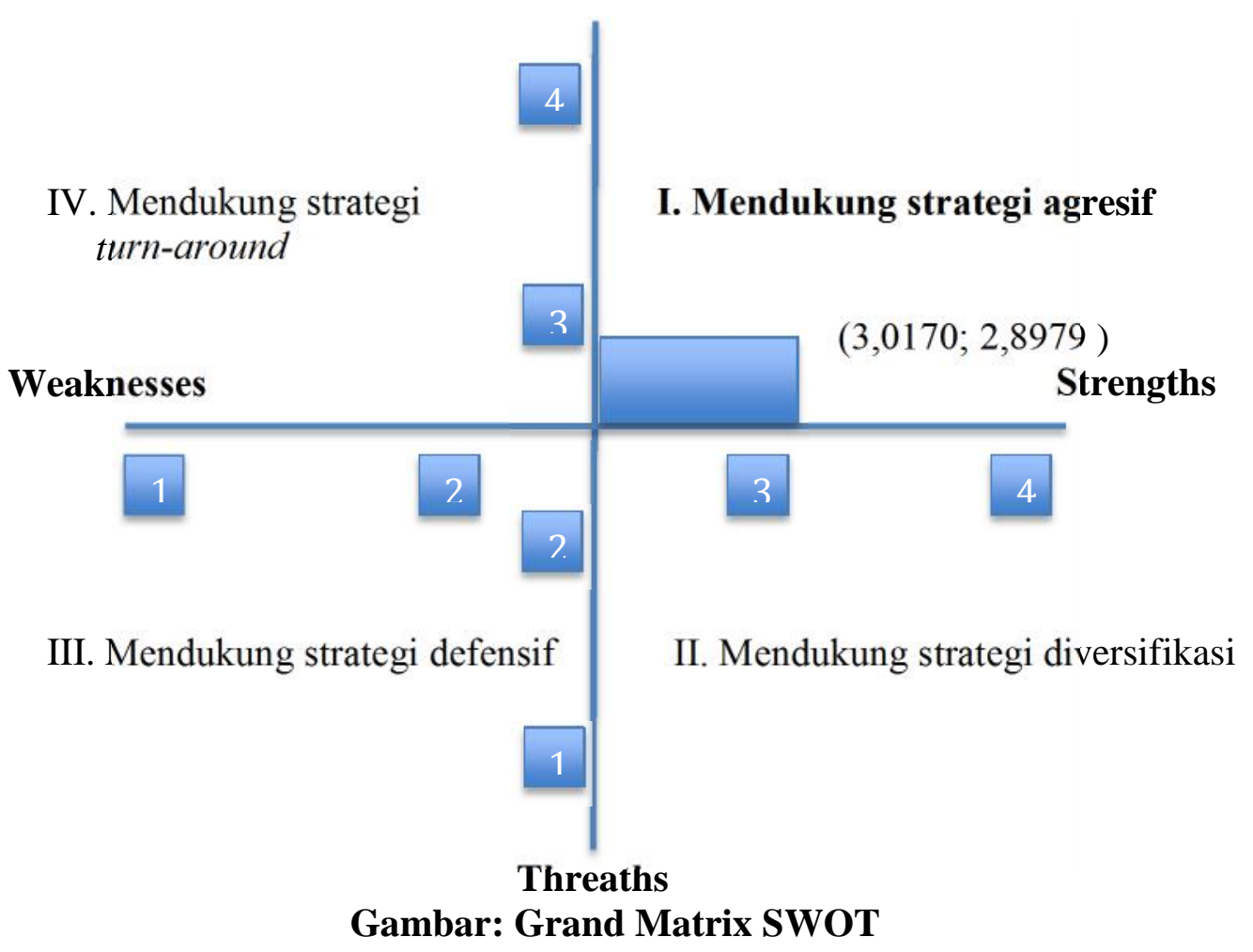


Tabel 5

Faktor Internal (Kekuatan dan Kelemahan)

\begin{tabular}{|l|l|l|}
\hline Faktor Internal & \multicolumn{1}{|c|}{ Kekuatan } & \multicolumn{1}{c|}{ Kelemahan } \\
\hline Produk & Kualitas produk & Merek produk \\
\hline & & Penampilan produk \\
\hline Distribusi & Ketersediaan produk di pasar & \\
\hline & Pelayanan pemesanan produk & \\
\hline Promosi & Promosi pemasaran & \\
\hline Harga & Harga sesuai kualitas & \\
\hline Citra & Citra produk & \\
\hline
\end{tabular}

sumber: data primer, diolah

Tabel 6

Faktor Eksternal (Peluang dan Ancaman)

\begin{tabular}{|l|l|l|}
\hline \multicolumn{1}{|c|}{ Faktor Internal } & \multicolumn{1}{|c|}{ Peluang } & \multicolumn{1}{c|}{ Ancaman } \\
\hline Daya beli & Daya beli konsumen & Perubahan pemasaran \\
\hline Teknologi & & \\
\hline Inovasi & Inovasi produk & \\
\hline Pertumbuhan & Pertumbuhan pasar & \\
\hline Persaingan & Kondisi persaingan & \\
\hline
\end{tabular}

sumber: data primer, diolah

\section{Implikasi Bisnis}

Strategi pertumbuhan (Growth Strategy) sebagai konsekuensi posisi usaha Darma Karya di Kuadran I dapat dilaksanakan dengan melakukan strategi pengembangan pasar (market development strategy) dan strategi pengembangan produk (product development strategy). Strategi pengembangan pasar dapat dilakukan oleh kelompok usaha Darma Karya mengingat usaha ini memiliki beberapa kekuatan di antaranya distribusi produk yang baik. Hal ini dibuktikan dengan ketersediaan produk di pasar secara kontinyu. Ketersediaan produk di pasar tersebut ditunjukkan oleh mudahnya konsumen menemukan produk Darma Karya serta adanya pelayanan yang cukup baik pada saat pemenuhan pemesanan produk. Kekuatan lainnya adalah produk pesanan dapat diterima tepat waktu sesuai perjanjian yang dibuat antara konsumen (pemesan) dengan pelaku usaha, tanpa adanya kendala pertukaran produk dan pembayarannya.

Promosi produk yang dilakukan usaha Darma Karya cukup berhasil meskipun belum optimal. Promosi produk masih "getok tular" dari mulut ke mulut yang mempromosikan produk tersebut karena kepuasan konsumen ketika mengkonsumsi produk. Perkembangan teknologi belum dapat dimanfaatkan secara maksimal karena masih terkendala pemahaman dan kemampuan pelaku usaha dalam menggunakan teknologi terkini dalam pemasaran produk masih berupa SMS untuk pemesanan produk saja. Para pelaku usaha belum mampu menggunakan secara maksimal media sosial untuk memasarkan produknya. Padahal perubahan pemasaran dengan menggunakan teknologi sudah mulai dilakukan oleh UMKM lainnya. Oleh 
karenanya pengembangan SDM dan kesiapan sarana-prasarana dalam memanfaatkan teknologi untuk menujnang pemasaran produk yang kini masih menjadi kendala (ancaman) di Kelompok usaha makanan olahan Darma Karya perlu memperoleh perhatian serius oleh DPPM UII dalam pengabdiannya di mitra ini. Jika kendala-kendala tersebut dapat ditanggulangi maka pengembangan pasar dengan memanfaatkan perkembangan tehnologi, misalnya dengan melakukan penetrasi pasar baru di kabupaten/kota lain di DIY akan dapat dilakukan lebih mudah, lebih efisien dan efektif.

Strategi pengembangan produk dapat dilakukan usaha Darma Karya karena usaha ini memiliki keunggulan dalam hal kualitas produk dan harga produk sesuai dengan kualitas yang dirasakan konsumen. Hal ini menjadikan konsumen akan tetap setia karena harga jual produk dinilai konsumen wajar, tidak mahal dibandingkan kualitas yang diterima. Merek produk harus dapat ditangani lebih serius dengan membuat merek produk yang lebih baik dan menarik. Pemilihan jenis huruf (font) dan bentuk merek perlu memperoleh penanganan para ahli, agar merek produk Darma Karya lebih mudah dikenali dan menarik perhatian konsumen. Begitupula penampilan produk harus dikemas lebih baik lagi melalui perbaikan desain kemasan serta adanya informasi bahan baku pembuat produk serta tanggal kadaluwarsa produk. Hal ini akan memberi dan membangun kepercayaan konsumen ketika akan mengkonsumsi produk.

Melalui upaya serius dalam perbaikan kondisi-kondisi tersebut maka hal itu akhirnya akan dapat membantu dalam membentuk citra produk yang positif terhadap produk yang dihasilkan Kelompok usaha makanan olahan Darma Karya ini.
Dampaknya diharapkan hal itu akan dapat menjadikan konsumen merasa puas terhadap produk yang dikonsumsinya dan juga akan dapat mendorong konsumen melakukan pembelian kembali (repurchasing) karena keinginan konsumen memperoleh/membeli produk tidak terhalangi dan dapat terpuaskan.

\section{Rekomendasi}

1. Kelompok usaha Darma Karya harus terus memperoleh perhatian dari DPPM UII dan pemerintah daerah melalui Dinas-dinas terkait untuk bisa terus memajukan usaha ini, mengingat manfaat yang banyak dirasakan stakeholder (pemangku kepentingan) dengan perkembangan usaha ini. Manfaat ini baik dilihat dari sisi bisnis, sosial dan ekonomi secara komprehensif. Strategi agresif (strategi pertumbuhan) sebagai hasil kajian ini dapat diterapkan pada Kelompok usaha makanan olahan Darma Karya melalui pengembangan pasar dan pengembangan produk.

2. Pengembangan pasar (market development) dapat dilakukan dengan melakukan pemasaran ke daerah baru, misalnya masuk ke kabupaten/kota di DIY selain Kabupaten Sleman, dengan memanfaatkan secara optimal kemajuan teknologi, peningkatan pelayanan, serta membangun citra positif produk.

3. Pengembangang produk (product development) dapat dilakukan dengan terus melakukan inovasi produk, diferensiasi produk serta strategi bukan harga. Konsumen harus terus dapat ditingkatkan nilai tambah yang dirasakan dalam mengkonsumsi produk dari Darma Karya ini.

\section{Referensi}

Aldaba, Rafaelita M. (2012). SME Development: Narrowing the 
Development Gap in the ASEAN Economic Community. Philippine Journal of Development, Vol. XXXIX, No. $1 \& 2$, Second Semester 2012, pp. 143

Alshomrani, Saleh. (2012). Hybrid SWOTAHP Analysis of Saudi Arabia EGovernment. International Journal of Computer Applications, Vol. 48, No. 2, June 2012, pp. 1

Cant, Michael. (2012). Challenges Faced by SME's in South Africa: Are Marketing Skills Needed?. International Business \& Economic Research Journal, Vol. 11, No. 10, October 2012, pp. 1107

Franco, Maria; Santos, Maria de Fatma; Ramalho, Isabel \& Nunes, Cristina. (2014). An Exploratory Study of Entrepreneurial Marketing in SMEs, The Role of the Founder-Entrepenur. Journal of Small Business and Enterprise Development, vol. 21, No. 2, 2014, pp.265-283

Haryani, Endang. (2012). Accounting System for Small Business in Indonesia (Case Studi Convention Business in Tingkir Lor Village). Journal of Arts, Science \& Commerce, Vol. III, Issue 2(1), Aril 2012, pp. 104

Helms, Marilyn M \& Nixon, Judy. (2010). Exploring SWOT Analysis - Where are We Now? A Review of Academic Research from the Last Decade. Journal of Strategy and Management, Vol. 3, No. 3, 2010, pp. 215-251

Ke, Yongjian; Zhao, Xinbo; Wang, Yingying \& Wang ShouQing. (2009). SWOT Analysis of Domestic Private Investment in Developing Infrastructure Projects in China. Journal of Financial Management of
Property and Contruction, Vol. 14, No. 2, 2009, pp. 152-170

Kusumastuti, Retno; Safitri, Nurul \& Khafian, Nidaan. (2015). Developing Innovation Capability of SME through Contextual Amidexterity. International Journal of Administrative Science \& Organization, Vol. 22, No. 1, January 2015, pp. 51

Lamprinopoulou, Chrysoula \& Tregear, Angela. (2011). Inter-firm Relations in SME Clusters and the link to Marketing Performance. Journal of Business \& Industrial Marketing, Vol. 26, No. 6, 2011, pp. 421-429

Mirzakhani, Maliheh; Parsaamal, Elahe \& Golzar, Abolghasem. (2014). Strategy Formulation with SWOT Matrix: A Case Study of Iranian Company. Global Business and Management Research: An International Journal Vol. 6, No. 2, 2014, pp. 150-168

Resnick, Sheilagh; Cheng, Ranis; Brindley, Clare \& Foster, Carley. (2011). Aligning Teaching and Practice: A Study of SME Marketing. Journal of Research in Marketing and Entrepreneurship, Vol. 13, No. 1, 2011, pp. 37-46

Sinaga, Selvie. (2013). Management and Programs of Intellectual Property Rigths for Small Medium Enterprises in Indonesia. International Journal of Arts \& Sciences, Vol. 6, No. 2, 2013, pp. 615-636

Subramoniam, Suresh; Al-Essai, Salim AN; Al-Marashadi, Ahmed AM \& Al-Kindi, Ali MA. (2010). SWOT Analysis on Oman Tourism: A Case Study. Journal of Economic Development, Management, IT, 
Finance and Marketing, Vol. 2, No. 2, September 2011, pp. 1

Suryana, Yuyus; Bayu Kartib \& Jatnika,

Dika. (2013). Promotion and Product

Marketing Models of Small and Medium Enterprises (SMEs) through E-Commerce. Advances in Management \& Applied Economics, Vol. 3, No. 4, 2013, pp. 149-160

Suryaningrum, Diah Hari. (2012).

Knowledge Management and Performance of Small and Medium Entities in Indonesia. International Journal of Innovation, Management, and Technology, Vol. 3, No. 1, February 2012, pp. 35 